\title{
A Rare Case of
}

Granulomatosis with

Polyangiitis-Related

Periaortitis at the Ascending Aorta

\author{
상행대동맥에 발생된 육아종증 다발혈관염의 \\ 희귀 증례 보고
}

Acute aortic syndrome including intramural hematoma is a life-threatening disease encountered in the emergency department with high in-hospital mortality even when a timely diagnosis is made. Therefore, accurate differential diagnosis of acute aortic syndrome and its mimics is important to determine the patient's treatment plan. Until now, a few pathologic diseases mimicking aortic intramural hematoma such as periaortic lymphoma and immunoglobulin G4related periaoritis have been reported. Here, we report a rare case of granulomatosis with polyangiitis-related periaortitis misdiagnosed as aortic intramural hematoma presenting to the emergency department with chest pain and similar radiologic findings.

Index terms Granulomatosis With Polyangiitis; Aortic Diseases; Vasculitis; Spiral CT; PET-CT

\section{INTRODUCTION}

Granulomatosis with polyangiitis is a necrotizing granulomatous vasculitis mainly involving small and medium-sized vessels such as arterioles, capillaries, venules and arteries. This disease has a broad clinical spectrum ranging from localized disease (predominantly restricted to the respiratory tract) to a severe life-threatening form with involvement of multiple organs (the kidneys and lungs) (1). Moreover, uncommon manifestations of granulomatosis with polyangiitis such as periaortitis with ret- 
roperitoneal fibrosis have also been reported (2-4). However, there were few case reports of granulomatosis with polyangiitis involving the ascending aorta or aortic arch (5), and misdiagnosed as acute aortic syndrome such as aortic intramural hematoma. Such cases have only been reported with immunoglobulin G4 (IgG4)-related disease (6-8). We present the imaging findings of CT and 2-F-18-Fluoro-2-Deoxyglucose $\left({ }^{18} \mathrm{~F}-\mathrm{FDG}\right)$ PET/CT in a case of granulomatosis with polyangiitis-related periaortitis initially misdiagnosed as aortic intramural hematoma of the ascending aorta and aortic arch in a patient presenting to the emergency department.

\section{CASE REPORT}

A 58-year-old man presented the emergency department complaining of right shoulder and mid sternal pain. He also reported one day history of hoarseness. His initial physical examination was entirely normal. Laboratory test was normal except leukocytosis (white blood cell $=11800 / \mu \mathrm{L})$ and elevated C-reactive protein $(4.49 \mathrm{mg} / \mathrm{dL})$.

CT angiography showed hyperdensity and thickening of the ascending aorta and aortic arch with smooth intraluminal line (Fig. 1A, upper and middle panel). The Hounsfield units (HU) of the aortic wall was measured as approximately $40 \mathrm{HU}$ on the precontrast axial CT image and about $60 \mathrm{HU}$ on the contrast-enhanced axial CT image. CT also showed a low attenuating line within the thickened aortic wall on the precontrast axial CT images (Fig. 1A, arrowheads), which indicated a preserved fat plane around the aorta. This lesion extended to the proximal neck vessels with slight infiltration to the periaortic mediastinum and compression of the adjacent venous structures including the left innominate vein and superior vena cava. The remainder of abdominal aorta and major branch vessels were entire normal on the CT. As an incidental finding there was a 3.4-cm, well-defined mass with peripheral enhancement in the left upper lobe of the lung abutting the pleura (Fig. 1A, lower panel).

The cardiac surgeons and on-call radiologists agreed upon the possible diagnosis of aortic intramural hematoma (type A according to Stanford classification), considering the hyperattenuating thickening of the aortic wall on the CT and clinical manifestation of chest pain. The mass in the left upper lobe was presumed as an incidental benign tumor, lung cancer or metastasis. The alternative diagnosis of vasculitis involving the aorta and lung was also entertained, considering the slight enhancement of the aortic wall and/or periaortic soft tissue and lung mass. The possibility of periaortic and/or aortic malignancy such as sarcoma or lymphoma was also included in the differential diagnosis. The patient underwent emergency operation for repair of aortic intramural hematoma on the basis of chest pain and relevant imaging findings. In the surgical field, the cardiac surgeon found firm and vascularized soft tissues around the aorta, adhering to the superior vena cava, aortic arch branches, and left innominate vein. Based on these findings, the cardiac surgeon suspected the periaortic soft tissues as malignant tumor and performed a biopsy in the periaortic soft tissues. After the surgery, CT-guided percutaneous needle aspiration was performed on the lung mass in the left upper lobe.

${ }^{18} \mathrm{~F}$-FDG PET/CT were performed for further evaluation. ${ }^{18} \mathrm{~F}-\mathrm{FDG}$ PET/CT showed irregular hypermetabolic wall thickening with maximum standardized uptake value (maxSUV) 10.4 
Fig. 1. Granulomatosis with polyangiitis-related periaortitis at the ascending aorta in a 58-year-old man, presenting with chest pain.

A. Pre- and postcontrast CT scans (upper and middle panels) show hyperdense aortic wall thickening (arrows) and slight enhancement of the aortic wall. A linear low attenuating line is present within the aortic wall thickening (arrowheads), which indicates a preserved fat plane around the aorta. Postcontrast CT scans (lower panel) show a mass with peripheral enhancement abutting the pleura in the left upper lobe of the lung (arrows).

B. ${ }^{18} \mathrm{~F}-\mathrm{FDG}$ PET/CT shows increased FDG metabolism of the aortic wall (maxSUV $=10.4$ ). ${ }^{18} \mathrm{~F}-\mathrm{FDG}$ PET/CT shows increased uptake of the lung mass ( $\operatorname{maxSUV}=12.2$ ).

${ }^{18} \mathrm{~F}-\mathrm{FDG}=2-\mathrm{F}-18$-Fluoro-2-Deoxyglucose, maxSUV = maximum standardized uptake value
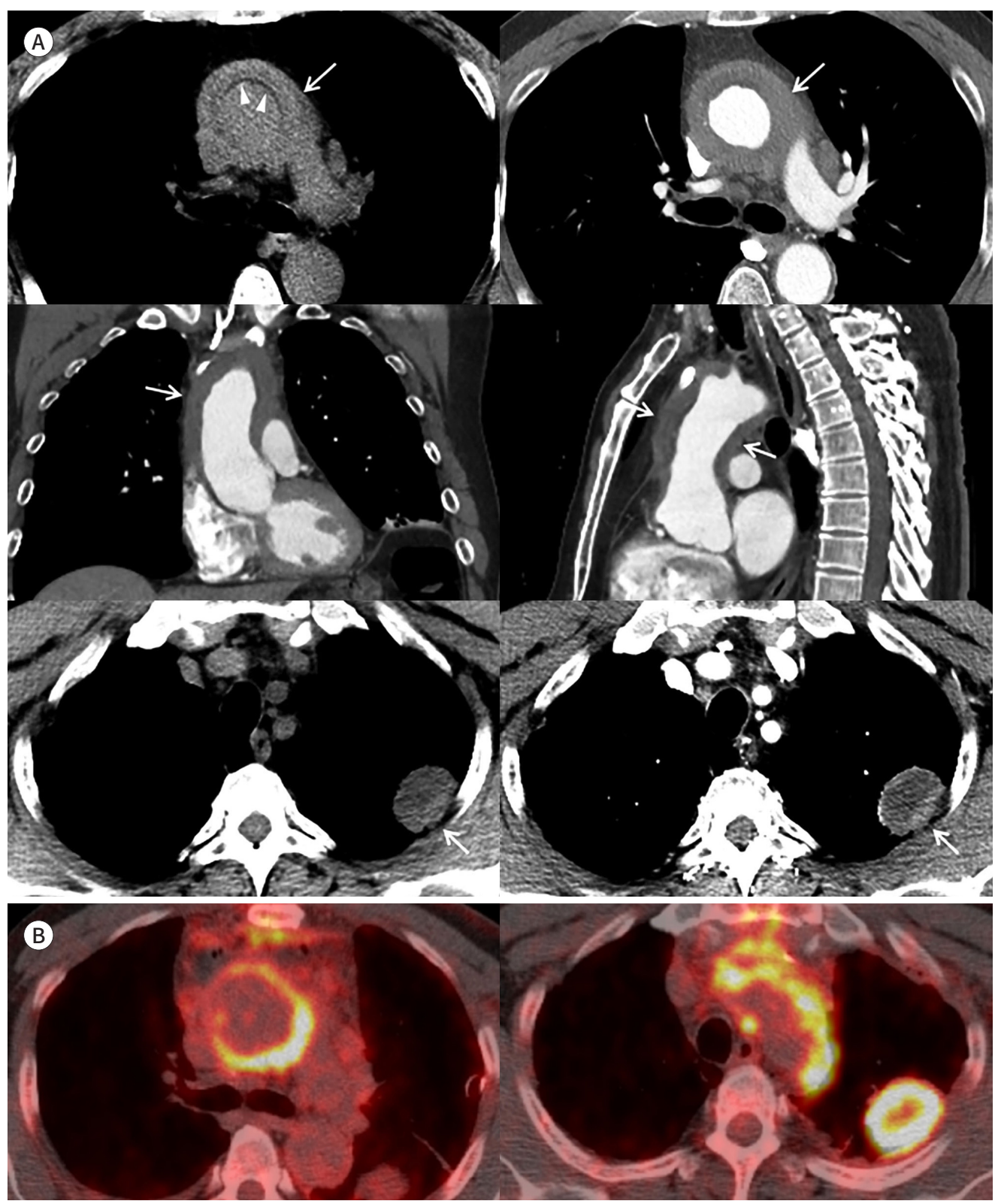

along the wall of the ascending aorta and aortic arch (Fig. 1B). The maxSUV in the mass of the left upper lobe was 12.2 (Fig. 1B).

Histological examination of periaortic tissue revealed chronic mediastinitis (Fig. 1C, upper panel). The mass in the left upper lobe was confirmed as chronic granulomatous inflamma- 
Fig. 1. Granulomatosis with polyangiitis-related periaortitis at the ascending aorta in a 58-year-old man, presenting with chest pain.

C. Microphotographs of periaortic tissue (upper panel) show lymphoplasmacytic infiltration with necrosis and fibrosis. Fibroblasts can be observed infiltrating the mediastinal fat. These findings suggest non-specific inflammations. There is no evidence of malignancy. Microphotographs of the mass in the left upper lobe (lower panel) show granuloma formations and necrosis.

$\mathrm{H} \& \mathrm{E}=$ hematoxylin and eosin stain
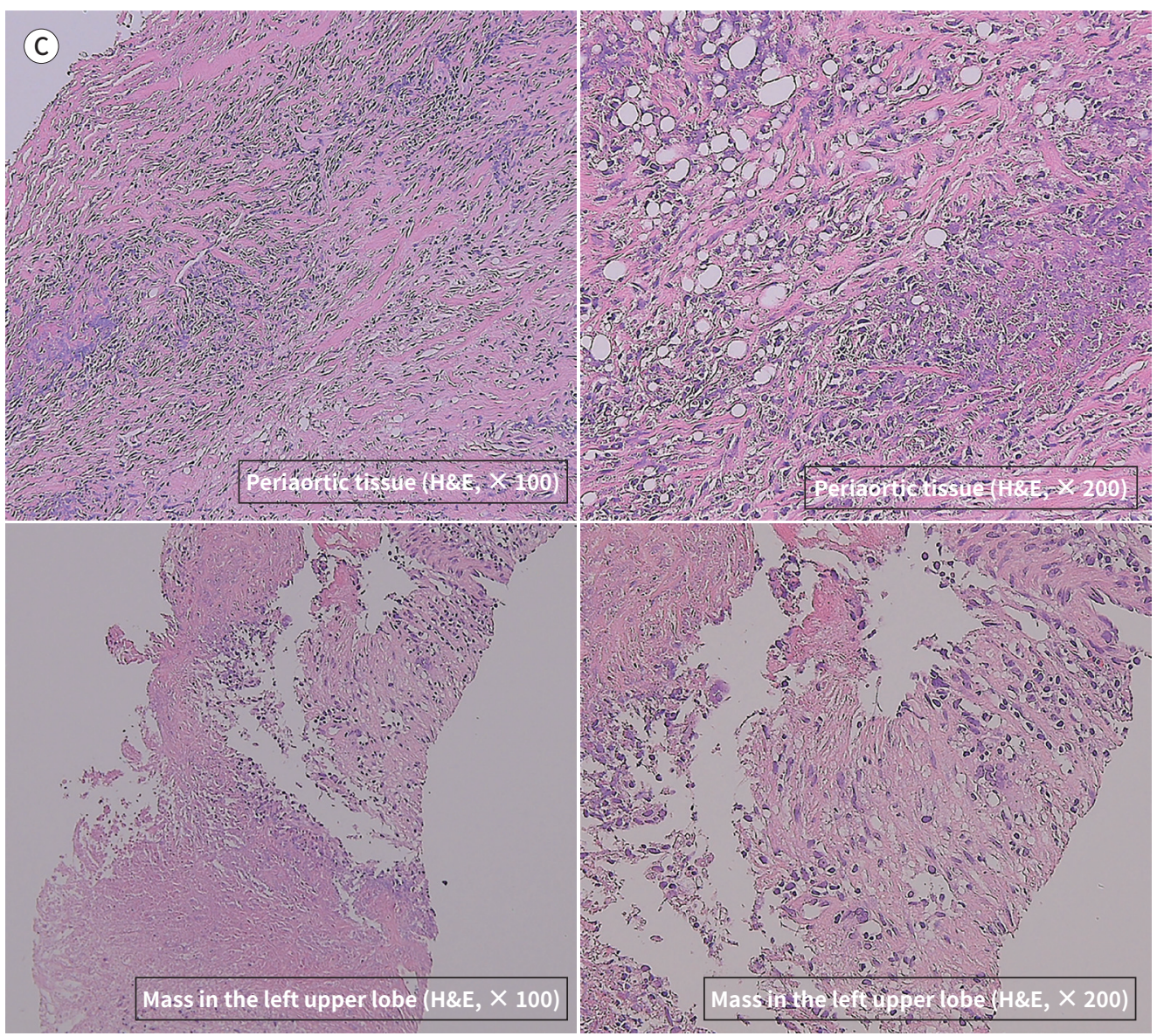

tion with necrosis (Fig. 1C, lower panel). IgG4 staining was negative and additional anti-neutrophil cytoplasmic antibody (ANCA) test was positive for cytoplasmic-ANCA. The patient was diagnosed as granulomatosis with polyangiitis and underwent steroid treatment. The follow-up CT scans (after 5 and 7 months) showed the decreased extent of periaortic soft tissue and decreased size of the pulmonary mass in the left upper lobe, but a new lung nodule in the right upper lobe.

\section{DISCUSSION}

Granulomatosis with polyangiitis is a necrotizing vasculitis. With Churg-Strauss syndrome and microscopic polyangiitis, granulomatosis with polyangiitis is considered as one of the ANCA-associated vasculitis (9). The diagnosis of granulomatosis with polyangiitis is based on the combination of clinical and laboratory findings. It classically manifests as upper and lower respiratory tract and renal disease (1). It rarely presents in the form of periaortitis, and 
it was, therefore, challenging to consider granulomatosis with polyangiitis as a part of the differential diagnosis at the initial presentation. There have been some case reports of granulomatosis with polyangiitis in the form of periaortitis $(2,3,4,5)$, especially in the abdomen. However, there were few reports of granulomatosis with polyangiitis mimicking aortic intramural hematoma as in our case. On the other hand, cases of IgG4-related disease mimicking aortic intramural hematoma have been previously reported $(7,8)$. Based on these reports, we also mentioned the possibility of IgG4-related periaortitis in the final CT report. Likewise, there was a report of periaortic soft tissue in a non-IgG4-related disease. Lee et al. (10) reported a case of non-IgG4-related fibrosclerosing periaortitis involving the thoracic aorta. The case reported periaortic soft tissue mass involving the thoracic aorta as in our case, but did not reach a specific diagnosis. Interestingly, PET-CT was performed in this case as well as in our case. Our case showed hypermetabolism with the maxSUV of 10.4 as compared with 5.5 in the case by Lee et al. (10) In fact, higher PET metabolism may be helpful for the exclusion of aortic intramural hematoma, but it is not likely to be of great benefit in the emergency department. In addition, in our case, PET did not help to distinguish whether periaortic soft tissue is due to malignancy or inflammation.

The differential diagnosis of aortic wall thickening on the CT includes aortic intramural hematoma, periaortitis or aortitis, and aortic wall malignancy. First of all, it is important to consider and exclude intramural hematoma in a patient with chest pain. Although PET-CT and MRI can help distinguish these lesions, it is difficult to perform these tests as a primary modality in emergency patients suspected of intramural hematoma. Therefore, it is important for radiologists to know the difference of CT findings of these diseases and to carefully examine CT images. When reviewing the CT, the preserved fat plane between the aortic wall and periaortic soft tissue may provide the most important diagnostic clue in differentiating periaortic inflammatory soft tissue and aortic intramural hematoma. This finding suggests that the lesion is not located in the aortic wall but is located outside the aorta. It is also important to always check the presence of mural enhancement. In our case, a lung mass incidentally detected could also be helpful in the diagnosis of vasculitis involving aorta, considering that the lung is the most frequently involved organ in the granulomatosis with polyangiitis (1). In the case of aortic wall malignancy, the intraluminal irregularity or exophytic appearance on the CT can be an important diagnostic clue.

We reported a rare case of granulomatosis with polyangiitis-related periaortitis involving the ascending aorta misdiagnosed as aortic intramural hematoma in the emergency department. It is challenging even for experienced radiologists to clearly distinguish these disease entities only by imaging findings. However, it is important to distinguish between aortic intramural hematoma and rare aortic involvement of vasculitis, such as granulomatosis with polyangiitis in order to avoid unnecessary operation and implement appropriate treatment. Radiologists need to be aware of the possibility of periaortitis as a mimic of aortic intramural hematoma and look for the diagnostic clues such as preserved periaortic fat plane and aortic wall enhancement.

\section{Conflicts of Interest}

The authors have no potential conflicts of interest to disclose. 


\section{REFERENCES}

1. Martinez F, Chung JH, Digumarthy SR, Kanne JP, Abbott GF, Shepard JA, et al. Common and uncommon manifestations of Wegener granulomatosis at chest CT: radiologic-pathologic correlation. Radiographics 2012;32:51-69

2. De RS, Serratrice J, Granel B, Disdier P, Bartoli JM, Pache X, et al. Periaortitis heralding Wegener's granulomatosis. J Rheumatol 2002;29:392-394

3. Shmagel A, Kokebie R, Meyer C. Granulomatosis with polyangiitis (Wegener's) presenting as a periaortic mass. J Clin Rheumatol 2011;17:442-443

4. Levin A, Kasem S, Mader R, Naparstek Y, Friedman G, Ben-Yehuda A. Wegener granulomatosis with back pain, periaortitis, and dural inflammation developing while receiving monthly cyclophosphamide. J Clin Rheumatol 2006;12:294-297

5. Blockmans D, Baeyens H, Van Loon R, Lauwers G, Bobbaers H. Periaortitis and aortic dissection due to Wegener's granulomatosis. Clin Rheumatol 2000;19:161-164

6. Lu MT, Millstine J, Menard MT, Rybicki FJ, Viscomi S. Periaortic lymphoma as a mimic of posttraumatic intramural hematoma. Emerg Radiol 2006;13:35-38

7. Moore DW, Hansen NJ, DiMaio DJ, Harrison WL. The great imitator: IgG4 periaortitis masquerading as an acute aortic syndrome on computed tomographic angiography. Radiol Case Rep 2016;11:287-291

8. Babur Güler G, Cantürk E, Güler E, Oran G, Demir GG, Akçevin A, et al. IgG4-related aortitis mimicking intramural hematoma. Anatol J Cardiol 2016;16:728-729

9. Gaffo AL. Diagnostic approach to ANCA-associated vasculitides. Rheum Dis Clin North Am 2010;36:491-506

10. Lee JY, Kim JH, Lee JY, Lim SH, Choi KH, Kim JS, et al. Non-IgG4-related fibrosclerosing periaortitis with multisystemic involvement. Korean J Med 2014;86:749-754

\section{상행대동맥에 발생된 육아종증 다발혈관염의 희귀 증례 보고}

\section{홍상협 ${ }^{1} \cdot$ 홍길선 ${ }^{*} \cdot$ 이충욱 ${ }^{1}$ 김기홍 ${ }^{2}$}

대동맥 벽 내 혈종과 같은 급성 대동맥 증후군은 응급실에서 마주하게 되는 생명을 위협하는 질환으로, 적절한 시간에 진단되어도 병원 내 사망률이 높은 질환들이다. 따라서 급성 대동 맥 증후군 및 이 질환과 오인될 수 있는 대동맥 주위 림프종, 면역글로불린 G4 연관성 대동맥 주위염과 같은 질환들에 대한 정확한 감별 진단은 환자의 치료 계획을 결정하는 데 중요하 다. 지금까지 대동맥 벽 내 혈종으로 오인될 수 있는 몇 가지 질환이 보고되었으나, 상행대동 맥에 발생된 육아종증 다발혈관염의 보고는 없었다. 저자들은 흥통을 주소로 응급실로 내원 한 58세 남자 환자의 CT에서 대동맥 벽 내 혈종으로 오인된 육아종증 다발혈관염의 1 예를 경 험하여 이를 보고하고자 한다.

${ }^{1}$ 울산대학교 의과대학 서울아산병원 영상의학과, 영상의학연구소, ${ }^{2}$ 제주한라병원 영상의학과 